\title{
Teenagers' Language Use in Batam: Language Variation
}

\author{
Suhardianto \\ Universitas Putera Batam \\ (suhardiantogamya@gmail.com)
}

\begin{abstract}
This research is aimed to figure out the phenomenon of language variation that is used among teenagers in Batam. The language variations which are created by teenagers contrast to the standard language formula. The aplication of that language can massively affect the standard language used in every formal situation. Knowing the basic knowledge about the variation, how are the process of constructing the non-standard language and the aspect of language can help the teenagers to avoid the devastating of standard language. The result of the research showed that in daily conversation among teenagers in Batam, the teenagers mostly used the non-standard language in their interaction involving the slang and colloquial languages. The use of these languages were frequently mixed by other languages, such as English language and regional language that teenagers imitated from Jakarta. Moreover, teenagers mostly used the slang and colloquial languages in the informal situation.
\end{abstract}

Keywords: Language variation, slang, colloquial.

In daily activity, there are many important things which become the human need, and the difficulties will happen if the human miss it. One of them is language. By using language, people can also share their knowledge, transfer any ideas and give information to each other. So that people will understand what others have felt and said. Language variation is a kind of language which is used in situation, condition, and society. According to Chaika (2008, p. 375), the language variety consists of social varieties and language function.

There are many varieties of language used in society. Varieties are used group to group, speaker to speaker, in terms of the pronunciation of a language, the choice of words and the meaning of those words, and even the use of syntactic constructions. In this fact, people may say the same thing in different ways. The speakers may use different style of their language depending on the particular context that is formal and informal.

The language variation can be seen from bilingualism and multilingualism because bilingualism and multilingualism use the language with many variations which are used in different situation, condition and society. According to Huri (2013), many bilingualism and multilingualism adapts at exploiting the theoretical possibilities of their linguistics repertoires.

The different language can be seen from morphology, vocabulary, and the language structure. This opinion is in line with Chaika's statement (2008, p. 10) saying that the different of language variety can be seen from vocabulary, morphology, and syntactic. Based on this reason, the writer would like to analyze the language style and words formation from morphology.

Teenager is very creative and productive human being in producing new word in 
communication and interaction. When talking about language variation it means cannot be separated from talking about teenagers' creativity. Teenagers tend to use variation of language in their daily communication especially in informal situation such as slang, colloquial, code mixing, code switching and regional language. According to Richard in Gemalasari (2013, p. 143), language variation is used for informal and formal situation speech variety which often serves as an in group' language such as teenagers, army and pop group. The use of language variation is considered as a result of the rapid growth of the new word. It is such kind of teenagers' creative expression to make the words simpler and efficient to speak.

The researchers found the language variation used among teenagers in Batam. Batam is an island under Kepulauan Riau province which has many groups of teenagers' community lives separately in some subdistricts such as Batu Aji, Tiban, and the center of Batam. The use of language variation in teenager community cannot be separated from the technology and information development. The teenagers see, hear, and imitate what comes to their life spontaneously. They hear the language from many aspects and try to modify and practice it in their community.

The language which is created by teenagers in their community slenderly constructed very different from the formal language which is mostly used by the people around them. They try to hide the meaning of words from others. The language by which the teenagers construct can be said as slang language. Slang is a language that may be created by mixing of words between regions within a country. Slang language of each country is different from each others. In Indonesia, for instance, is well known by slang language and more often used in everyday life. They are classified as non-formal languages.

From the phenomena of language variations used by teenagers described above, this research is aimed to find out the variation of language used by teenagers in Batam. The language will be categorized into the existed theories.

\section{Sociolinguistics}

Stockwell (2013, p. 11) states that sociolinguistics is a concerned with relationship between language and context in which it is used. It means that sociolinguistics deals with the social factors. Sociolinguistics is also interested in the different types of linguistics variation use to express and reflects social factor as slang that the writer wants to analyze. In addition, sociolinguistics is the radical wing of the discipline. Sociolinguists are field researchers; they go out collecting data from ordinary people about their actual language use, and on the basis of the evidence they construct theories as to how and why language changes. Sociolinguistics concerns with the correlation between such social factors and linguistic variation. The factors meaning is, age, gender, jobs, and religion.

The quotation means that the sociolinguistics relates to the people and language used. It also has a few fundamental concepts. They are speech community and social networks. Speech community is a concept of sociolinguistics to describe about unique language that is used by a group, just like jargon and slang. In addition, a social network is a way to link between someone to other people in different place. According to Chaer in Fasya (2013), "sociolinguistics is any study of language in relation to society". In addition, Chaika (2008) stated that sociolinguistics is concerned with the diversity of language as it related to various sociological factors such as participants, setting, topic, function, social distance, status, formality, and social factors that influence people in communication.

\section{Speech Variety}

Speech variety can be seen from social context and community in which they have 
the interaction. Yule (2010, p. 129) says that sociolinguistics is interested in the different type of speech variety use to express and reflect social factors. The social factors will prove important in describe and analyzing all kinds of interaction. In any situation linguistic choices will generally reflect the influence of one or more of the following components. The components are (1) The participant, who is speaking and who they are speaking to, (2) The setting or social context of the interaction, where they are speaking, (3) Topic, what being, talking about, (4) the function, why they are speaking. The language variety can be seen from standard language and non-standard language.

\section{Standard and Non-Standard Language}

According to Yule (2010, p. 236 ), a standard variety is generally one which is written and which has under gone some of regularization or codifications (for example, in a grammar and a dictionary); it is used for $\mathrm{H}$ (high) functions a long side a diversity of L (low) varieties.

A standard language variety is generally used in the news media and in literature and described in dictionaries and grammar and taught in school and to native speakers when they learn language as a foreign language. According to Debora (2013), non-standard language is variety that has indication or symbol from characteristic to set out of the way from norm of standard language. Nonstandard language shows greater variety than standard language. The higher social position of the non-standard speakers, the more nearly do they approach the standard language. For example:

Non-standard Language (Informal English)

1. can't

2. I'm

3. didn't

Standard Language (Formal English)

1. cannot

2. I am

3. did not

Based on the examples, it is seen that cannot, I am, and did not is the standard form of can't, I'm, and didn't. So the speakers often use the non-standard language in informal situation, and standard language use in formal situation or in formal conversation.

\section{Code Mixing}

Many people used code mixing when they interact with other people in society. The people mix two languages of national language and foreign language. The writer can find the language used mixed the one language to another language such as between Indonesia Language and English Language.

According to Sumarsih (2014), code mixing suggests the speakers in mixing up codes indiscriminately or perhaps because of in competence. Furthermore, conversational code mixing involves the deliberate mixing two languages without as an associated topic change. In general, code mixing functions as showing prestige of using English rather than mother tongue. Code mixing is a mix of word, phrase, and clause in one language to another language.

\section{Bilingualism}

While it is the case that even speakers a single language (putative monolinguals) control various styles and levels of that language, it is very common that people develop some knowledge and ability in a second language and so become bilingual. According to Spolsky in Sumarsih (2014) the simplest definition of a bilingual is a person who has some functional ability in a second language. This may vary from a limited ability on one or more domains, to very strong command of both languages (which is sometimes called balanced bilingualism). The assumption that they must be a single definition leads to confusion, such as when one person is talking about the highly skilled multiple-domain balanced bilingualism of an expert translator and interpreter, and the other the uneven skills of a recent immigrant. In describing the bilingualism of 
an individual, another set of differences often evident in the performance of certain internal function. Bilingual usually prefer one language for functions such as counting, doing arithmetic, dreaming (some people dream in language, other don't), cursing, or praying silently.One of special ability (not true in the case of all bilinguals) is the skill of translation fromone language to the other. Another useful approach to describe a bilingual's language used in by domains rather that by function.

\section{Multilingualism}

Multilingualism, in an individual speaker or in a social group, are the most obvious and salient cases of variation to observe. According to Trask (2001, p. 146), multilingualism is a person who knows and uses three or more languages by an individual or by group speakers such as the inhabitants of a particular region or nation.

With stylistic or dialectal variation, identifying each variety is harder and open to dispute, but with distinctly recognized language, there is generally agreement on the varieties and their names. Multilingual communities evolve in a number of ways. One is as a result of migration, the voluntary or involuntary movements of people speaking one language into the territory of people speaking another.

Multilingualism has been created by conquest and the subsequent incorporation of speakers of different languages into a single political unit. According to Bakar (2015), the study of language maintenance and language shift has thus become a central concern of sociolinguists interested in multilingual societies.

\section{Language Style}

According to Pardede (2012, p. 152) language varies according to its uses as well its users, according to where it is used and to whom, as well as, according to who is using it. It is known that language style is a language produced by addresser and writer caused by how the way using source language in choosing of word and pattern of arranging of the words. The study of that variation in language (style) which depends on the situation in which the language is used and also on the effect the writer wishes to create stylistics. Stylistics is concerned with the choices that available to a writer and the reason why particular forms and expressions are used rather than others.

\section{Language Style}

According to Pardede (2012, p. 115) style of language can be classified into informal and formal style. In informal styles, here, refers to the use of language for intimate condition such as slang and colloquial which are used among friends. They use them in some occasion and combine old words into new meaning. Usually, slang and colloquial varies from regions because they are developing in a community.

On the other hand, Holmes (2001, p. 22) states that informal language is the same with casual style. There are two styles of language that can be classified into casual language's circumference; they are slang and colloquial style. However, this research focuses on slang as the material of discussion.

Slang

According to Yule (2010), slang is used for a very informal speech variety which serves as an "in -group" language such as teenagers, army, pop group, etc. The word slang is used only known by the group itself. The word actually has informal language. The slang has been defines as one of those that everybody can recognize and nobody can define. Slang words almost could not be found in dictionary. Slang is informal, non- Standard English vocabulary that provides effective shorts cut in expression because it is often vivid and sharp. Like idiom, slang is part of native speaker's informal talk. Slang is traditionally considered as a vulgar, and rude form of language with a 
strong color of irreverence and yet vitality in a society. It is generally labeled as a linguistic taboo which should not be appearing in most formal social occasions. Slang is one of the language style belong to more information language that mostly used by youth. It will always be developed on and on appropriately with the youth's language development that can fulfill their need in using language (Zhou, 2013 , p. 209). There are some reasons why slang is used: (1) It conceals meaning from parents, (2) It identifies you as part of the tribe, (3) It defies authority (taking like rebel), (4) It makes one feels special \& important, (5) It excludes from other peer group.

There are some clues to identify forms or words of slang. Firstly, those words or form could only be understood by group or community itself. Secondly, slang is different with idiom, or any other language style. Thirdly, slang is something unique that could only be found in community and they create it for their own community.

Form of Slang

Forms of slang consist of word and phrase. One single word could be slang depending on the context, and it also applies on phrase (Paltridge, 2003, p. 46). Slang words are formed by a variety of processes of which the following are the main ones.

\section{Slang as Word}

Word is a row letter that is flanked by two spaces, and has meaning. In this research, the writer found the forms of slang as word based on part of speech, such as, noun ( N ), verb (V), adjective (Adj). Such discussion is classified based on part of speech that will be explained one by one (Gemilasari, 2013).

\section{Slang as Phrase}

Phrase is a combination of two words or more that have non predicative characteristic
(Gemilasari, 2013, p. 143). For the example:

Tom jambakers

Yupz bro,Randi can't join with us, coz, he got hold of some bad shit and he is really sick,

From example above, bad shit is categorized into phrase, because bad shit acts like a noun phrase. A phrase is a group of words which form a constituent and so function as a single unit in the syntax of a sentence.

\section{Meaning of Slang}

Meaning of slang is based on context. It cannot be analyzed by using common dictionary; it must be taken by real sources Yule (2010, p. 49). The word slang is only known by the group itself. The word actually has informal language. The slang has been defined as one of those that everybody can recognize and nobody can define. Slang words almost could not be found in dictionary. Slang is informal, non-standard English vocabulary that provides effective short cuts in expression because it is often vivid and sharp. Like idiom, slang is part of native speaker's informal talk.

\section{Colloquial}

Daily activity has conversational language. Generally, colloquial style is not really attention to pronunciation, choice, or words, or sentence structure. According to Trask (2001, p. 140), colloquial is words or phrases that are only used in utterances in spoken language. It used in casual conversation. Education native speakers of a language normally use colloquial speech in informal situation with friends, fellow workers and members of the family.

For examples:

1. Gimana kalau kamu dulu yang cerita tentang dirimu

From example, the word gimana are colloquial word, which means how in English Language. This word better not to use in formal speaking or writing, because 
this word is not depend on standard language.

\section{Gue gak benci kok sama lu!}

From example, the word gue means aku in Inndonesia Language and / in English Language, and gak is colloquial word which means no in English language. This word used by teenager in informal situation.

3. Dia udah lewat.

From example, the word $u d a h$ are colloquial word, it means already in English language. This word used by teenagers in informal conversation with their friend or family.

\section{Method}

The place of the research is done in Batam which involves teenagers who live in Batu Aji, Tiban, and Batam Center. Population of this research is all teenagers who live in Batam especially the teenagers who live in Batu Aji, Tiban and Batam Center and the range of their age is indicated around 12-21 years old. The researchers use purposive and snowball sampling technique which data are collected on purpose of the research and will be added if it is needed. This is in line with Sugiyono's opinion (2014, p. 301) that purposive sampling is technique of collecting data sampling which is purposed to take the data based on the research need. Snowball sampling is the technique of collecting data sampling which is collected from the small data range to the bigger one.

In collecting the data, the researchers use Metode Simak with Teknik Sadap and Libat Cakap proposed by Sudaryanto (2015:205). Metode Simak is similar to the observation method in other science researches. The process of collecting data can be seen from the steps (1) the researchers come and join to the teenagers' community in their communication,(2) the researchers record the process of interaction among speakers from teenagers' community (3) the researchers transcribe all conversation in the form of phonemic (4) the researchers start to analyze the data collected from teenagers.

In analyzing data, the researchers apply the technique proposed by Sudaryanto (2015, p. 27) that is called as Metode Padan and Metode Agih. Metode Padan is used to find out the variation of languages and some aspects in which they are used in teenagers' community. Meanwhile, applying Metode Agih is to figure out the forms of construction of language variation. The technique for Metode Padan applied by researcher team is Mitra Wicara technique or pragmatic technique.

\section{Result and Discussion}

In this chapter, the writers would like to describe the data collected based on the data theories. The writer focuses their analysis on the variation of languages style of teenagers used found in Batam. The writers take the data by doing observation and recorded the conversation among teenagers silently and analyzed them to find out the variation of languages used and aspect of used by teenagers in Batam. It is found many variation of languages style which are produced by teenagers in Batam on the form of code mixing and the form of word formation of language style.

\section{Forms of Variation of Language Style Used in Batam}

In this part of the research, the writers would like to analyze the forms of language style which are produced by teenagers in Batam. In this research, the writers analyze two forms of variation of language style, they are: slang words, and colloquial.

\section{Slang Words}

Slang is a variety of speech characterized by newly coined and rapidly changing vacabulary, used by the youth or 
by the social and professional groups for ingroup communication and thus standing to prevent understanding by the rest of speech community. Slang consists of the informal words, non-standard vocabularies that provide effective shot cuts in expression. At the analysis, the witers found some some words that considered to be slang words. There are as follow.

\section{Memang iya, aku tahu itu blo'on}

(That is true, I know his is stupid)

From example (1) above, the word bloon is called as a slang word which means bodoh in Indonesia language or stupid in English language. The word bloon is mostly used by the youth in Informal situation.

2. Kenapa lu jutek banget sih sih sama gue? (Why do you get angry to me?)

From example (2) above, the word jutek is also called as a slang word which means marah in Indonesia language or angry in English language. This word is usually used by the teenagers in informal conversation. This word normally used in Jakarta Dialect.

3. Gue akan langsung balik begitu nyokap gue sembuh

(I will back when my my mother fine)

From example (3) above the word nyokap is a slang, which means Ibu in Indonesia language or mother in English language. The word nyokap is non standard word that usually used in informal situation. This word normally used in Jakarta and imitated by teenagers in Batam.

4. Padahal, tadi gue rada grogi (Honestly, I got nervous just now) From example (4), the word grogi is a slang, it means takut in Indonesia language or scare in English language. This word is usually used by teenagers in informal situation, because grogi is non-standard language.

5. Jangan sampai gue bogem ya.

(Don't let me hit you)

From example (5), the word bogem is a slang. It means tinju in Indonesia language and fist or hit in English language. This word is used by the youth in informal conversation, for example with friends. Teenagers use this word if they feel disoppointed.

\section{Dumel Sabrina dalam hati}

(Sabrina got grumble)

From example (6) above, the word dumel is a slang, it means gerutu in Indonesia language or grumbling in English language. The word dumel is non standard word that usually used in informal situation.

\section{Aduh-aduh, gilingan deh yey}

(Oh god, You are crazy)

From example, (7) above the word gilingan is a slang, it means gila in Indonesia language or crazy in English language. This word is used by teenagers in Informal conversation with friends, and these words used by transvestite.

\section{Colloquial}

Colloquial is the type of speech used in everyday, informal situation when the speaker is not paying particular attention to pronunciation, choice of words, or sentence structure. This data mostly used in Jakarta dialect.

8. Rin, gue pinjem telepon bentar ya?

(Rin, lend me your phone for a while) From example (8) above, the word gue, pinjem, and bentar are colloquial words, which means I, to borrow and later in English language, or pinjam and sebentar in Indonesia language. These words are usually used in daily conversation by teenagers to make the conversation more relax.

9. Gak ada kerjaan banget.

(No occupation)

From example (9) above, the word gak, kerjaan, and banget are colloquial words, that means no occupation, and very in English language. These words usually 
used by teenagers in informal situation, for example with friends.

10. Tapi karena sering ngerasa sakit

(Because of feeling sickness)

From example (10), the word ngerasa is colloquial word, which means to feel in English language. This word better not to use in formal speaking because it does not depend on standard language.

11. Gue denger kakak lu sakit ya

(I heard that your sister was sick)

From example (11) above, the word gue, denger and $l u$ is colloquial word, which means I, listen and you in English language. This word used by teenagers in informal situation, form example with their friend.

12. Cepetan deh pulang

(Go back hurry up)

From example (12) the word cepetan is colloquial word, it means hurry up in English language. This word occur in informal conversation because it is not depend on standard language.

13. Tinggal promosi dikitaja, kamu pasti lakukok. (Just do promotion, it will be sold out) From example (13), the word dikit and aja, are colloquial word, it means little and only in English language. This word used in daily conversation by teenagers.

14. Aku jadi nyesel pernah ngobrol ama dia. (I regeret ever talked to her)

From example (14), the word nyesel and ngobrol ama are colloquial word, it means to regret and speak with in English language. This word used by teenagers in informal situation.

\section{Sam, gimana kabarmu?}

(Sam, how are you)

From example (15), the word gimana is colloquial word, it means how in English language. The word gimana is non-standard word word that usually used in informal situation and informal conversation.
(Don't worry)

From example (16), the word gak usah are colloquial word, which means not necessary in English language. This used by teenagers in informal situation, with friends and family. This words is style from teenagers in informal conversation.

17. Bener ya, kamu gak apa-apa duduk sendirian disana?

(All right, it's oke leaving you sitting alone here?)

From example (17) above, the word bener and gak are colloquial word, which means right and no in English language. This used by teenagers in informal conversation. This word better not to use in informal situation because this word is not depend on standard language.

18. Gimana kalau kamu dulu yang cerita tentang dirimu.

(Why don't you start to tell me the history about yourself)

From the example (18), the word gimana is colloquial word, which means how in English language. This word better not to use in formal speaking or writing, because this word does not depend on standard language.

19. Gue gak benci kok sama lu (I don't hate you)

From example (19), the word gue means aku in Indonesia language and 'I' in English language, and gak is colloquial word which means 'no' in English language. This word used by teenagers in informal situation.

20. Dia udah lewat

(He has passed)

From example (20) above, the word $u d a h$ are colloquial word, it means already in English language. This word used by teenagers in informal conversation with their friend or family.

\section{Gak usah cemas deh}




\section{Conclusion}

Based on the description above, the writers concluded about the variation of language styles produced by teenagers in Batam. The language used has a relationship with the situation or feeling that teenagers want to express and show it in utterances. The utterances are communicated by teenagers in Batam. The language is not only use in written but also has a relationship with the style of language conducted the meaning of utterances to make the conversation more interesting, because in Batam, the teenagers used the style in informal situation.

In this research, the variations of language used by teenagers in their interaction are slang style and colloquial. From the data found and analyzed can be concluded that, the teenagers speak slang and colloquial in informal situation among them. In the other hand, the slang language and colloquial forms are also mostly used in some cities like Jakarta, Bandung and Surabaya. To get more knowledge about the process of getting slang and colloquial language, it is needed to do advance research and planned for the next research.

\section{References}

Bakar, Mukhlis Abu. (2015). Malay, English and Religion: Language Maintenance in Multilingual Singapore. Journal Issue in Language Studies, 4(1).

Chaika, Elaine. (2008). Language the Social Miror. (4th ed.). Cengage Learning Products are represented in Canada By Nelson Education Ltd.

Debora, Irene. (2013). The Ssing of Casual Style in ELT for Young Learners (Sociolinguistics Perspective). Journal Advances in Language and Literary Studies, 4(1). doi:10.7575.

Fasya, Mahmud \& Euis Nicky Marnianti.
(2013). Variable Sosial sebagai Penentu Penggunaan Slang Makian dalam Bahasa Indonesia. Rineka Cipta. Jakarta.

Gemilasari, Nor. (2013). An Analysis of Word Formation of Slang Words Found in Short Stories in Teenager Magazines Aneka Yess. English Language and Literature. Padang.

Huri, Daman. 2013. Penguasaan Kosa Kata Kedwibahasaan Antara Bahasa Sunda dan Bahasa Indonesia Pada Anak-Anak Sebuah Analisis Deskriptif-Komperatif. Jurnal Pendidikan UNSIKA. 2(1).

Paltridge, Brian. (2006). Discourse Analysis. MPG Ltd., Bodmin, Cornwall. London.

Pardede, Hilman. (2012). Introduction to Sociolinguistics. From General to Local Perspective. Halaman Moeka in collaboration with LLC Publishing. Jakarta-Batam.

Stockwell, Peter. (2013). Sociolinguistic A Resource book for Student. Routledge is an imprint of the taiylor \& Francis group.

Sudaryanto. (2015). Metode dan Aneka Teknik Analisis Bahasa Pengantar Penelitian Wahana Kebudayaan Secara Linguistik. Sanata Dharma University Press. Yogyakarta.

Sugiyono. (2014). Metode Penelitian Kombinasi, Mixed Metode. Alfabeta. Bandung.

Sumarsih, Masitowarni, et al. (2014). Code Switching and Code Mixing in Indonesia: Study in Sociolinguistics. Journal English language and Literature Studies, 4(1).

Trask, R.L. (2001). A Student's Dictionary of Language and Linguistics. Oxford University Press. Inc. London.

Yule, George. (2010). The Study of Language. Cambridge University Press. New York.

Zhou, Yanchun \& Yanhon Fang. (2013). A Sociolinguistics Study of American Slang. Theory and Practice in Language Studies, 3(12), 2209-2213. 
